\title{
PERANCANGAN SISTEM INFORMASI PEMODELAN LABOR PRAKTIKUM PROSES MANUFAKTUR BERBASIS WEB
}

\author{
Elmawati $^{1}$, Nofriadiman ${ }^{2}$, Harsiska Yulita ${ }^{3}$ \\ ${ }^{1}$ Sistem Informasi, Sekolah Tinggi Teknologi Industri Padang \\ Email : elmawati@sttind.ac.id, nofriadiman@sttind.ac.id, harsiska19@gmail.com
}

\begin{abstract}
ABSTRAK : Laboratorium merupakan tempat mahasiswa untuk melakukan eksperimen-eksperimen dari teori yang telah didapatkan berfungsi untuk meningkatkan pemahaman mahasiswa terhadap suatu materi yang telah dipelajari. Terbatasnya sumber-sumber untuk panduan praktikum proses manufaktur yang mengakibatkan kurang percaya diri ketika melaksanakan praktek karena berhubungan dengan kecelakaan kerja. Maka dari itu dibutuhkan sebuah website untuk mempermudah mahasiswa dalam proses pembelajaran untuk mencari informasi kegiatan praktikum yang dibutuhkan, untuk mempermudah mahasiswa dalam melakukan proses dibutuhkan panduan untuk pemahaman berupa website proses manufaktur dalam bentuk video dan gambar sehingga pemahaman terhadap proses akan lebih baik.
\end{abstract}

\section{Kata Kunci : Sistem, Informasi, Manufaktur}

\section{PENDAHULUAN}

Perkembangan teknologi informasi mendorong manusia untuk bertindak lebih cepat dalam berbagai hal untuk mencapai tujuan yang telah ditetapkan. Dalam mencapai tujuan tersebut dibutuhkan sarana dan prasana yang canggih, salah satunya penggunaan komputer. Komputer adalah sekumpulan alat elektonik yang saling bekerja sama yang dapat menerima data (input), mengolah data (proses), memberikan informasi (output) serta terkoordinasi dibawah kontrol program yang tersimpan dimemorinya.

Komputer akan mempermudah kinerja manusia dalam melakukan semua proses kerja dan proses pembelajaran. Pembelajaran labor praktikum proses manufaktur berbasis web merupakan salah satu produk unggulan hasil kemajuan teknologi informasi dan laboratorium yang dapat digunakan sebagai alternatif untuk membantu mahasiswa dalam meningkatkan produktivitas menyelesaikan proses. Laboratorium merupakan tempat mahasiswa untuk melakukan eksperimeneksperimen dari teori yang telah didapatkan berfungsi untuk meningkatkan pemahaman mahasiswa terhadap suatu materi yang telah dipelajari.

Mata kuliah proses manufaktur berguna untuk pemahaman belajar yang memerlukan praktek langsung di laboratorium, pada saat praktek jika hanya mengandalkan sumbersumber pembelajaran dari Dosen dan koleksi buku diperpustakaan dirasa kurang efektif untuk memfasilitasi serta pandangan terhadap proses belajar-mengajar tanpa adanya sumbersumber pembelajaran dari mahasiswa, artikel di web, informasi dari forum dengan tujuan memperoleh hasil yang maksimal, karena praktek dilabor pada proses manufaktur dapat mengakibatkan setiap mahasiswa merasa tidak yakin untuk melaksanakan proses termasuk yang berhubungan dengan keselamatan kerja, dimana kekhawatiran akan terjadi ketika ada kesalahan waktu praktek, kecelakaan dalam praktek bisa saja terjadi apabila kurang berhati-hati dan kurang memahami bagaimana cara penggunaan alat pelindung diri, mesin, serta pengukuran bahan yang tidak sesuai dengan bentuk dan tujuan untuk mendapatkan hasil yang maksimal dan dapat mengakibatkan kerugian bahan yang cukup besar, sedangkan manufaktur merupakan suatu bagian penting dari ekonomi industrial. Karena manufaktur menciptakan barang-barang untuk kehidupan kita, dari yang berukuran sangat besar sampai yang terkecil. Secara defenisi manufaktur sebagai pembuatan barang atau benda mengungkap sedikit tentang kerumitan masalah tersebut. Akibat dari pelaksanaan proses manufaktur yang dilakukan dengan tanpa adanya pengetahuan serta panduan ini banyaknya mahasiswa gagal dalam melaksanakan praktek, kesalahan yang terus terulang, mengakibatkan kerugian bahan melakukan proses. 
Maka dari itu dibutuhkan sebuah website untuk mempermudah mahasiswa dalam proses pembelajaran untuk mencari informasi yang dibutuhkan, untuk mempermudah mahasiswa dalam melakukan proses dibutuhkan panduan salah satunya adalah website proses manufaktur dalam bentuk video dan gambar sehingga pemahaman terhadap proses akan lebih baik. Hal ini menjadi pembelajaran efektif karena mahasiswa dapat belajar sendiri secara aktif tanpa bantuan instruktur ataupun asisten seperti sistem yang berjalan dengan format tampilan berbasis web cukup membantu mahasiswa untuk dapat mengikuti praktikum secara mandiri, instruktur ataupun asisten hanya untuk mengawasi mahasiswa ketika melaksanakan praktikum proses manufaktur di labor. Berdasarkan dari uraian diatas maka penulis tertarik untuk melakukan penelitian mengenai "Perancangan Sistem Informasi Pemodelan Labor Praktikum Proses Manufaktur Berbasis Web".

Berdasarkan uraian latar belakang diatas, untuk memperjelas permasalahan yang timbul maka penulis mencoba mengidentifikasikan permasalahan tersebut. Berikut ini adalah halhal yang menjadi permasalahan dalam praktek dilabor proses manufaktur:

1. Banyaknya kesalahan yang terjadi ketika melaksanakan praktikum proses manufaktur.

2. Pelaksanaan praktikum yang berbahaya memerlukan alat safety sebagai Alat Pelindung Diri (APD) yang memerlukan biaya besar.

3. Terjadinya kecelakaan kerja bagi peserta praktikum.

4. Tidak terciptanya alat rancangan yang sesuai dengan bentuk dan tujuan untuk mendapatkan hasil yang maksimal.

Pada penelitian ini, penulis membatasi masalah pada Perancangan Sistem Informasi Pemodelan Labor Praktikum Proses Manufaktur di Sekolah Tinggi Teknologi Industri (STTIND) Padang dengan berbasis web.

Ditinjau dari latar belakang dan di identifikasi masalahnya maka dirumuskan permasalahan sebagai berikut:

1. Bagaimana cara merancang sistem informasi pemodelan labor berbasis web untuk meningkatkan pemahaman belajar praktikum?
2. Bagaimana cara mencegah terjadinya kecelakaan pelaksanaan praktikum proses manufaktur?

Penelitian ini bertujuan untuk:

1. Untuk merancang sistem informasi pemodelan labor proses manufaktur berbasis web yang dapat meningkatkan pemahaman belajar praktikum.

2. Mencegah terjadinya kecelakaan pelaksanaan praktikum proses manufaktur.

\section{METODOLOGI PENELITIAN}

Jenis penelitian yang penulis lakukan adalah penelitian Terapan (Applied research). Penelitian terapan adalah penelitian yang diarahkan untuk mendapatkan informasi yang dapat digunakan untuk memecahkan masalah. Penelitian terapan dilakukan dengan tujuan untuk menerapkan, menguji dan mengevaluasi masalah-masalah praktis sehingga dapat dimanfaatkan untuk kepentingan manusia baik secara individual maupun kelompok.

Untuk memperoleh data dan informasi dalam menyusun penelitian, maka diperlukan metode dalam penelitian. Adapun langkahlangkah dalam perancangan sistem informasi pemodelan labor praktikum proses manufaktur yang digunakan peneliti dalam memperoleh data yaitu :

1. Menyediakan data-data yang diperlukan untuk sistem informasi pemodelan labor proses manufaktur.

2. Menyediakan software untuk membangun sebuah website seperti macromedia dreamweaver 8 yang bertujuan untuk merancang sebuah website, media server gratis seperti xampp untuk memastikan bahwa website tersebut sudah berhasil atau tidak, tetapi xampp tidak akan berguna jika tidak ada mozila atau google crome sebagai media penghubung internet.

3. Setelah website dirancang maka semua data yang ada akan di input, dan melakukan implementasi tahap penerapan dari proses perancangan yang telah dilakukan dalam sebuah website bagi semua mahasiswa dan pengguna komputer.

4. Melakukan testing dengan tujuan untuk memastikan website ini berfungsi sebagai panduan untuk pemahaman proses pada saat pratikum bagi mahasiswa,maka website ini dapat dijadikan sebagai panduan untuk praktikum dilabor bagi mahasiswa STTIND Padang. 


\section{HASIL DAN PEMBAHASAN}

\section{Implementasi Sistem}

Implementasi sistem adalah suatu prosedur yang dilakukan pada tahap sistem dalam dokumen yang disetujui dan menguji kemudian menginstal dan menggunakan program yang dibuat.

Tujuan Implementasi sistem adalah sebagai berikut :

1. Memperhitungkan bahwa sistem yang sudah dibuat sesuai dengan kebutuhan

2. Menyelesaikan desain sistem yang ada dalam dokumen sistem yang disetujui.

3. Mendokumentasikan program serta prosedur-prosedur yang diperlukan oleh dokumen desain sistem yang diuji.

Untuk merancang dan

mengimplementasikan sistem yang dirancang diperlukan sebuah alat berupa komputer sebagai media yang dapat membantu dalam pengaplikasikannya. Pada komputer terdapat tiga komponen penting yang seperti hardware, software dan brainware.

\section{Desain Database}

Mendesain database pada bab ini menggunakan XAMPP yang didalamnya terdapat PHP MyAdmin, yang dimulai dari menginstal Software tersebut serta mengikuti langkah-langkah dalam menginstal hingga selesai. Setelah proses instalasi selesai, aktifkan XAMPP dan mengaktifkan Apache dan MySql. Dilanjutkan dengan membuka browser Mozilla Firefox atau google crome, ketikkan http://localhost/XAMPP. selanjutnya pada tool XAMPP pilih PHP MyAdmin, maka kita akan masuk pada tampilan PHP MyAdmin

Setelah berada di menu PHP MyAdmin, selanjutnya dibuat database dengan cara memilih menu Create New Database dan diberi nama kampus Seperti tampilan gambar dibawah ini :

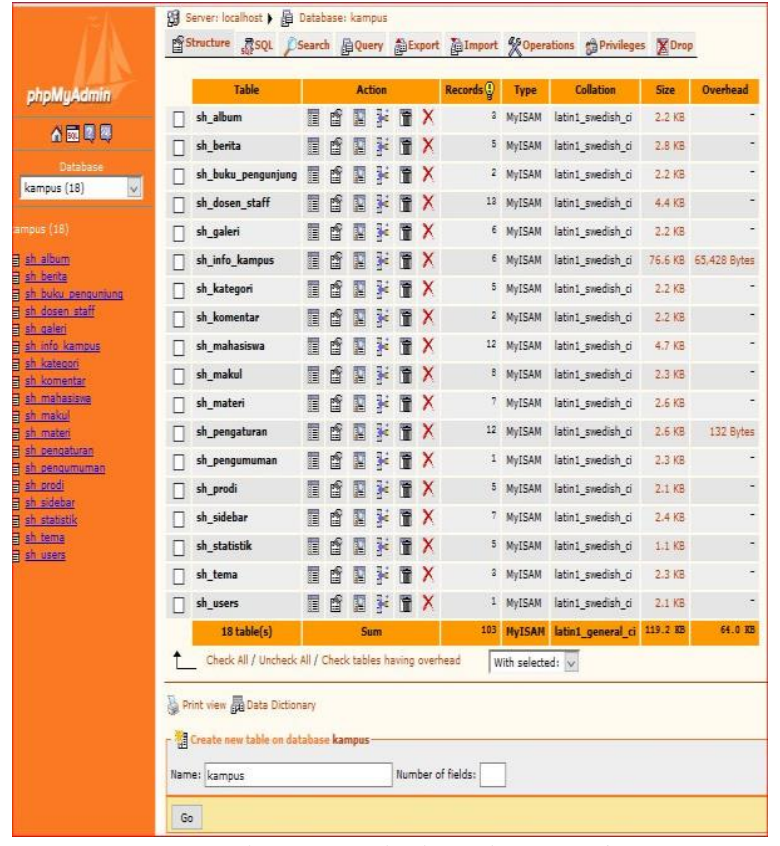

Gambar 1. Tabel Pada Database

\section{Pengujian Sistem}

Pada bab ini akan dijelaskan lebih rinci tentang sistem yang telah dibuat. Pengujian sistem dilakukan untuk menguji hubungan antara program aplikasi yang dibuat dengan elemen yang lain dalam sistem informasi. Adapun tujuan dari pengujian sistem ini adalah untuk memastikan semua elemen sistem sudah terhubung dengan baik. Pada pengujian ini sistem akan dilihat perbedaan antara sistem yang lama dengan yang baru. Berikut merupakan penjelasan beserta gambar tentang Perancangan Sistem Informasi Pemodelan Labor Praktikum Proses Manufaktur Berbasis Web.

\section{Tampilan Menu Utama}

Pada tampilan menu utama ini menampilkan menu home, profil, berita, informasi, warga kampus, galeri, buku pengunjung, penmaru yang dapat di akses oleh mahasiswa. 


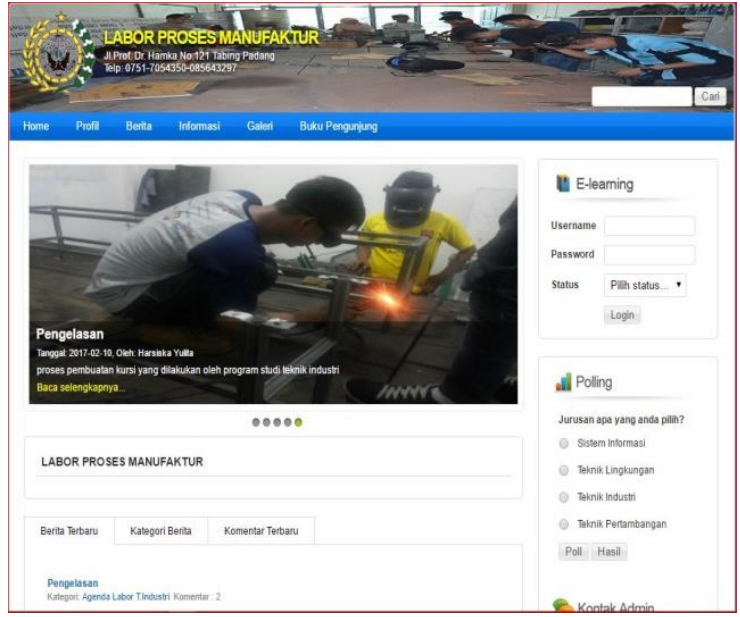

Gambar 2. Tampilan Menu Utama

\section{Menu Login Mahasiswa}

Setiap mahasiswaharus login terlebih dahulu untuk masuk pada form pembelajaran (e-learning), dimana setiapmahasiswa mempunyai username dan password yang berbeda dengan mahasiswa lainnya.

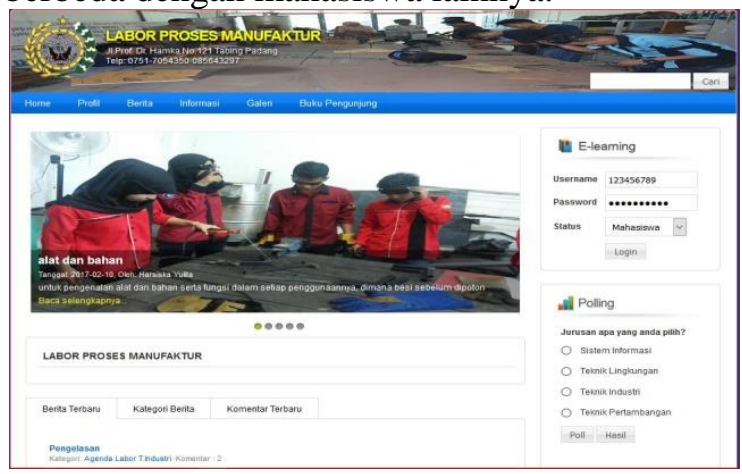

Gambar 3 Menu Login Mahasiswa

\section{Menu Home Mahasiswa}

Menampilkan apa saja yang ada pada home mahasiswa.

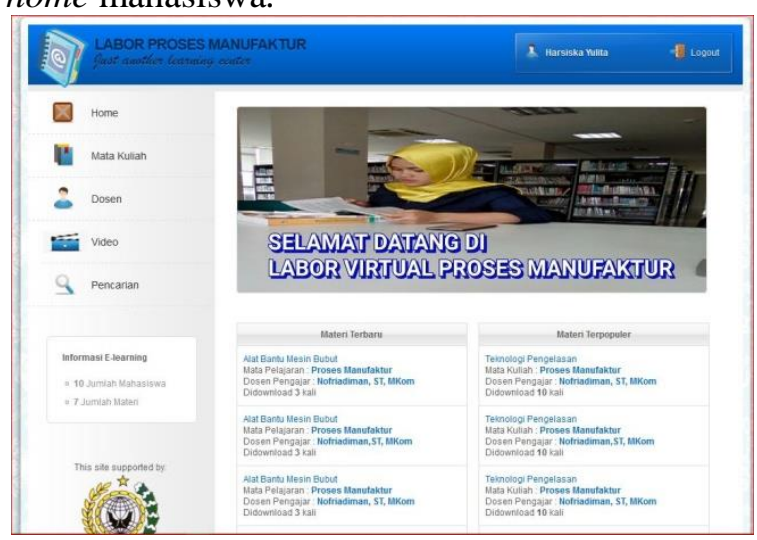

Gambar 4. Menu Home Mahasiswa

\section{Menu Video Tutorial}

Memberikan video panduan proses manufaktur yang dapat dilihat secara langsung pada website.

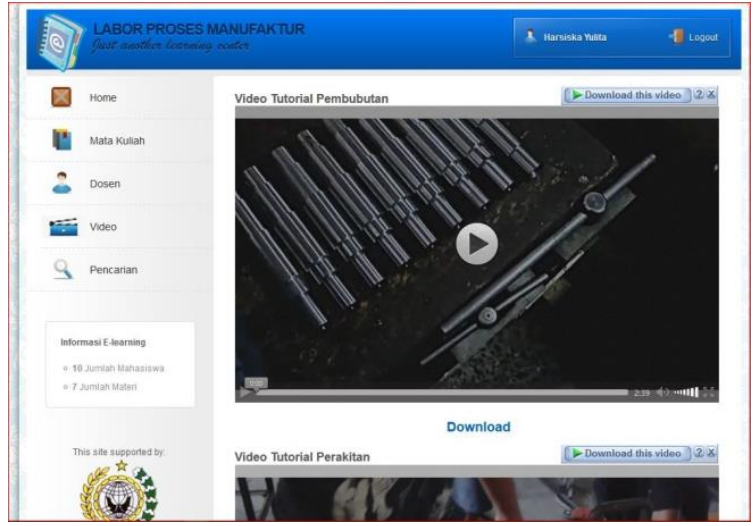

Gambar 5. Menu Video Tutorial

\section{KESIMPULAN}

Berdasarkan hasil penelitian pada sistem informasi labor proses manufaktur, maka penulis mengambil kesimpulan, sebagai berikut :

1. Memberikan panduan dan informasi serta meningkatkan pemahaman belajar pada saat praktikum di labor proses manufaktur yang ada pada kampus STTIND Padang.

2. Memberikan pemahaman terhadap tata cara pelaksanaan proses praktikum agar tidak terjadi kecelakaan kerja pada saat pelaksanaan praktikum.

\section{DAFTAR PUSTAKA}

Emanuel, Andi Wahju Raharjo. Timotius Witono. Wilfridus Bambang Triadi Handaya. Cara Praktis Membangun Situs E-Learning dengan Teknologi Open Source. Yogyakarta: Graha Ilmu. 2008.

Fatta, Hanif Al. Analisa \& Perancangan Sistem Informasi untuk keunggulan Bersaing Perusahaan \& Organisasi modern. Yogjakarta: Penerbit Andi. 2007.

Hartama, Dedy Efrizal. Pemrograman web dengan HTML, CSS dan Javascrip. Yogyakarta: Penerbit Andi. 2012. http://www.proweb.co.id/articles/web_ design/website_adalah.html.

Jhon, A. Schey. Proses Manufaktur. Yogyakarta: Penerbit Andi. 2009.

Kusumaningsih Rr.Yuliana Rachmawati, Catur Iswahyudi, Erma Susanti. Pengembangan Model Laboratorium 
Virtual Sebagai Solusi Keterbatasan

Sumber Daya Pembelajaran.

Yogyakarta: 2014.

Maimunah. Perancangan Aplikasi Forum

Diskusi pada Media E-Learning

Berbasis Web. CCIT Jurnal Perguruan

Tinggi Raharja. Tangerang. 2010.

Mcleod, Raymon. Sistem Informasi Manajemen. Jakarta. PT. Prenhallindo. 2001.

Simarmata, Janner. Rekayasa Web. Yogyakarta: Penerbit Andi. 2010.

Sakur, Stendy B. PHP 5 Pemrograman Berorientasi Objek (Konsep dan Implementasi). Yogyakarta: Penerbit Andi. 2010.

Sugiarti, Yuni, S.T.M.Kom. Analisa dan Perancangan UML Generated VB6. Yogyakarta. 2013.

Waluyo, Dr. Minto Ir. MM. Panduan dan Aplikasi Structural Equation Modelling (untuk aplikasi model dalam penelitian teknik industri, psikologi, sosial dan manajemen). PT. Indeks Jakarta. 2011. 